\title{
Cytometric blood phenotyping in free-living white-eyed parakeet (Psittacara leucophthalmus) ${ }^{1}$
}

\author{
Nathan R.N. Cruz ${ }^{2 *}(\mathbb{D})$, Mariele de Santi2 (D), Larissa Ayane N. Braz ${ }^{2}$, \\ Karin Werther ${ }^{2}$ (D) and Áureo E. Santana ${ }^{2}$ (i)
}

\begin{abstract}
Cruz N.R.N., Santi M., Braz L.A.N., Werther K. \& Santana A.E. 2021. Cytometric blood phenotyping in free-living white-eyed parakeet (Psittacara leucophthalmus). Pesquisa Veterinária Brasileira 41:e06688, 2021. Faculdade de Ciências Agrárias e Veterinárias, Universidade Estadual Paulista "Júlio de Mesquita Filho", Via de Acesso Prof. Paulo Donato Castellane s/n, Bairro Rural, Jaboticabal, SP 14884-900, Brazil. E-mail: nathancruzbr@gmail.com, nathan.cruz@unesp.br

This study aimed at performing cytometric phenotyping of the blood samples from free-living, young white-eyed parakeets (Psittacara leucophthalmus), stained with 3,3-dihexyloxacarbocyanine [DiOC $\left._{6}(3)\right]_{\text {. DiOC }}(3)$-stained whole blood samples from 19 free-living, young white-eyed parakeets were analyzed by flow cytometry and cell types were distinguished by their typical fluorescence in blue laser channel (FL-1) and SSC (side scatter). It was possible to differentiate erythrocytes $(58.3 \pm 13.6)$ from leukocytes $(32.4 \pm 13.1)$ and some of the leucocyte subpopulations: lymphocytes/thrombocytes (29.7 \pm 7.7$)$, monocytes (30.6 \pm 8.5$)$, and granulocytes (5.9-26). However, lymphocytes and thrombocytes could not be sorted in the plots. Our study determined that the predominant population in white-eyed parakeet (P. leucophthalmus) was lymphocytes, thrombocytes, and monocytes in the leucocytes gates in comparison to the granulocyte population. The cytometry method and use of $\mathrm{DiOC}_{6}(3)$ stain was available for parakeets blood samples and can be studied and applied to other species of parrots.
\end{abstract}

INDEX TERMS: White-eyed parakeet, Psittacara leucophthalmus, Psittaciformes, avian, flow cytometry, blood cell phenotyping, leukocytes, $\operatorname{DiOC}_{6}(3)$, wildlife animals.

RESUMO.- [Fenotipagem citométrica do sangue de maritacas jovens de vida-livre (Psittacara leucophthalmus).] Este estudo teve como objetivo realizar a fenotipagem citométrica com 3,3-di-hexiloxacarbocianina [DiOC 6 (3)] de amostras de sangue de maritacas jovens de vida-livre (Psittacara leucophthalmus). As amostras de sangue total, coradas com $\mathrm{DiOC}_{6}(3)$ de 19 maritacas de vida livre, foram analisadas por citometria de fluxo e os tipos de células foram distinguidos por sua fluorescência típica no canal laser azul (FL-1) e SSC (dispersão lateral). Foi possível diferenciar eritrócitos $(58,3 \pm 13,6)$ de leucócitos $(32,4 \pm 13,1)$ e algumas subpopulações de leucócitos: linfócitos/trombócitos $(29,7 \pm 7,7)$, monócitos $(30,6 \pm 8,5)$ e granulócitos $(5,9-26)$, entretanto, linfócitos e trombócitos não puderam ser diferenciados em

\footnotetext{
${ }^{1}$ Received on March 17, 2021.

Accepted for publication on March 31, 2021.

${ }^{2}$ Faculdade de Ciências Agrárias e Veterinárias (FCAV), Universidade Estadual Paulista "Júlio de Mesquita Filho" (Unesp), Via de Acesso Prof. Paulo Donato Castellane s/n, Bairro Rural, Jaboticabal, SP 14884-900, Brazil. *Corresponding author: nathancruzbr@gmail.com, nathan.cruz@unesp.br
}

duas populações distintas. Nosso estudo determinou que a população predominante $P$. leucophthalmus foi mononuclear agranulocítica em comparação com a taxa de aquisição da população granulocítica. A metodologia de citometria de fluxo com uso da coloração de $\operatorname{DiOC}_{6}(3)$ foi aplicável a amostras sanguíneas das maritacas e pode ser estudado e aplicado para outras espécies de psitacídeos.

TERMOS DE INDEXAÇÃO: Maritacas, Psittacara leucophthalmus, Psittaciformes, aves, citometria de fluxo, fenotipagem, leucócitos, DiOC6(3), animais selvagens.

\section{INTRODUCTION}

Blood evaluations are an important practice in medicine that allows diagnosing diseases, monitoring the patient's health, and interpreting the physiological responses concerning the disease challenge. In avian, the hematological practice is useful for understanding the effects of diseases and stress (Inoue et al. 2002). However, the automatic count by impedance methods is difficult because nucleated erythrocytes are considered 
like small lymphocytes or thrombocytes. The availability of antibodies for differentiating blood cells by immunophenotype is a problem when compared to mammalians samples because of antibodies in relation to species-specific and cost antibodies for free-living animals (Uchiyama et al. 2005).

Automated techniques, initially developed for blood evaluation in humans, have also become routine procedures in veterinary medicine. However, automatic blood counting methods, adapted and widely used for diagnosis in mammals have limited use in avian hematology due to the presence of nucleated erythrocytes and thrombocytes (Walberg 2001, Welles et al. 2009).

The flow cytometry offers with speed and accuracy the possibility to analyze and discriminate the cell populations on the basis to size (FSC) and complexity (SSC), and when complemented with a fluorochrome (Morgan et al. 1993) it provides a simple method for differential a cell or your metabolic activities. An example, Inoue et al. (2002), Moritomo et al. (2002) and Uchiyama et al. (2005) described the use of specific fluorescent lipophilic dye, 3,3-dihexyloxacarbocyanine $\left[\mathrm{DiOC}_{6}(3)\right]$ for differentiation through flow analysis with quail, chicken, turkey, and fish blood cells. With this dye is possible to discern the white blood cells from nucleated erythrocytes sin previous cell lysis, and quantify and evaluation cellular behavior like used to CD45 antigen (De Boever et al. 2010). The DiOC $_{6}(3)$ can be used a fluorescent dye in the mitochondrial activity, sperm analysis, differentiation and cell growth analysis, in addition to endoplasmic reticulum evaluation (Sabnis et al. 1997).

A detail in the avian clinical practice about blood sampling there is a limited amount of blood by live weight, particularly, when the avian patient is a minimal size or debilitated (Clark et al. 2009). Here, there are principal advantages of cytometry for this species, with few amounts of blood it possible to performer hematology and immunological studies.

The aim of this study was to recognize the cytometric phenotyping with 3,3-dihexyloxacarbocyanine [DiOC 6 (3)] of free-living young white-eyed parakeets (Psittacara leucophtalmus).

\section{MATERIALS AND METHODS}

Animal procedures and management protocols were approved by the Ethics Committee on Animal Use (CEUA) of the "Faculdade de Ciências Agrárias e Veterinárias", "Universidade Estadual Paulista 'Júlio de Mesquita Filho'" (FCAV-Unesp, protocol number 006483/18) and by the "Instituto Chico Mendes de Conservação da Biodiversidade" (ICMBio no. 62783-1).

The 19 free-living white-eyed parakeets (Psittacara leucophthalmus) used in this study were admitted at the Veterinary Hospital from the FCAV-Unesp of Jaboticabal, São Paulo, Brazil, in the early year on period of hatching of the eggs for this species in this region of the country.

These parakeets frequently nest near or inside human constructions, which provide close contact between the birds and humans. Mostly, these birds have an ingenious behavior and leave the nest before learning to fly then were found on the ground by people, which brings them to the hospital like a rescue service.

All parakeets of this study presented good body condition, normal hydration, normal behaviour and absence of clinical alterations at the time of blood collection. After a hosting period, the birds are released in nature. The gender of the parakeets was not determined, approximately 3-4 months old and weighed between 94 and 172 grams. After physical restraint, a $0.2 \mathrm{ml}$ blood aliquot was collected from the right jugular vein with a heparinized syringe. The samples were kept under refrigeration $\left(4-8^{\circ} \mathrm{C}\right)$ until the analysis.

The DiOC 6 (3) (3,3-dihexyloxacarbocyanine, Molecular Probes, Eugene/OR, U.S.A.) staining was conducted following the methodology previously proposed (Inoue et al. 2002). A stock $\mathrm{DiOC}_{6}(3)$ solution was previously prepared in ethanol for analysis at $500 \mu \mathrm{g} \mathrm{ml}-1$. Right before staining, the stock solution was diluted ten times in Hank's Balanced Salt Solution no calcium/magnesium (HBSS) (Thermo Fischer Scientific, Brazil). Fresh blood $(10 \mu \mathrm{l})$ was delivered into a test tube (Falcon 2059, Becton Dickinson, San Jose/CA, U.S.A.) and gently mixed with HBSS $1 \mathrm{x}(1950 \mu \mathrm{l})$ and the diluted dye solution $(40 \mu \mathrm{l})$, followed by incubation at room temperature for 10 minutes.

After stained with $\mathrm{DiOC}_{6}(3)$, the blood cells were analysed using flow cytometry (FACSCanto II, BD BioScience, Philadelphia, 2004) with BD FACSDiva ${ }^{\mathrm{TM}}$ software. Forward scatter (FSC), side scatter (SSC), and green fluorescence (FL-1/488nm) of each cell was measured. The workflow for gate strategy can be visualized in Figure 1-6. Ten thousand events in a single cell gate were acquired (FSC-A x FSC-H). After, only positive events $\left[\mathrm{DiOC}_{6}(3)+\right.$ gate $]$ were analyzed in the blue laser channel (FL-1 - 488nm) with detection of $\approx 525 \mathrm{~nm}$ were labeled FITC-A and FITC-H in the graphs.

The positive events with $\mathrm{DiOC}_{6}(3)+$ stain were divided into two gates concerning fluorochrome vs. complexity (FITC-H vs. SSC-H) that were R1 (red blood cells - RBC) and R2 (white blood cells WBC) like related by Inoue et al. (2002) and Moritomo et al. (2002). Additionally, cell number was expressed as average and percentage related to the population hierarchy.

The white blood cells (WBC) in R2 gate were divided in three gates in relation FSC vs. SSC and the gates were labeled in granulocyte (GRAN), monocyte (MON) and lymphocyte/thrombocyte like related by Inoue et al. (2002) and Moritomo et al. (2002). All values were submitted to Shapiro-Wilk Test $(p \leq 0.05)$ in the R software (R Core Team 2011) and were described as a descriptive statistic.

\section{RESULTS AND DISCUSSION}

To the best of our knowledge, this is first report of dye phenotyping in free-living white-eyed parakeets (Psittacara leucophthalmus). The gates strategic of flow cytometry can visualized in Figure 1-6. In dotplot of FL-1-A x SSC-A, two distinct population were observed: 1) low FL1 (red blood cells - RBC) with 58.3\% (44.7-71.9); and, 2) high FL1 (white blood cells - WBC) with $32.4 \%$ (19.3-45.5).

With our results, we found a similar cellularity behaviour as described by Inoue et al. (2002), Moritomo et al. (2002) and Uchiyama et al. (2005). Con basis in the literature, we considered a subdivision in WBC dotpot into three population by the FSC-A x SSC-A. These populations were gated in granulocytes (R2-1), monocytes (R2-2), and lymphocytes/ thrombocytes (R2-3). Following, were created the population hierarchy based in size (FSC) and complexity (SSC) of graph sorting population (Table 1).

A percentage of granulocytes were visualized in R2-1 gate (heterophils, eosinophils and basophils) of 9.7\% (5.926), monocytes in R2-2 gate of $30.6 \%$ (22.1-39.1) and lymphocytes/thrombocytes in R2-3 of 29.7\% (22-37.4). In weight characteristics (FSC), the monocyte were larger $(147,136.7-157.3)$ than granulocytes $(93 ; 81.4-104.6)$, and lymphocytes/thrombocytes (73.6, 69.9-77.3). 

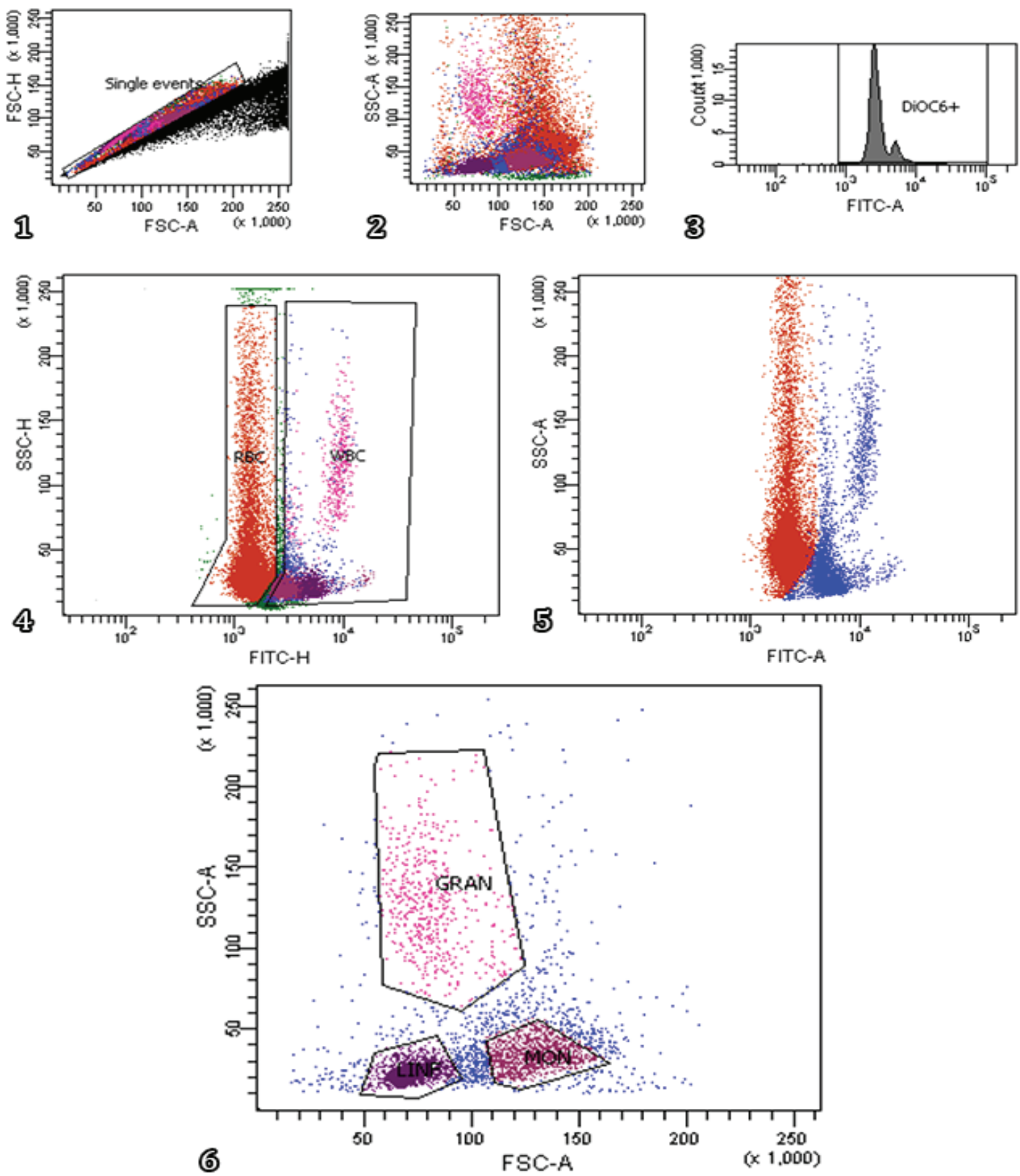

Fig.1-6. Workflow gate strategy analysis by flow cytometry of of whole blood of free-living young white-eyed parakeet (Psittacara leucophthalmus) stained with 3,3-dihexyloxacarbocyanine [DiOC 6 (3)]. (1) Single events gate (FSC-A x FSC-H). (2) Fluorochrome positive events marked by DiOC $_{6}(3)$ in FL1 (488nm). (3) Dotplot cytogram (FITC-H x SSC-H) with two regions R1 (red blood cells - RBC) and R2 (white blood cells - WBC). (4) Cell population distinct by fluorescence in FL1 (FITC - A) were revealed: R1 and R2. (5) Labelled gated regions R1 (red blood cells - RBC) and R2 (white blood cells - WBC). (6) Graph sorting of WBC (R2) population in FSC vs. SSC was divided into three different groups named: granulocytes (GRAN) = R2-1, monocytes (MONO) = R2-2, and lymphocytes/thrombocytes (LINF) = R2-3. 
Ours results show that erythrocytes were the predominantly population and in white blood cells gate, the lymphocytes/ thrombocytes were more prevalence in relation the granulocyte and monocyte. Lymphocytes and thrombocytes could not be sorting in the plots using only $\mathrm{DiOC}_{6}(3)$, because, these cellularity has the lower size (FSC: 73.6 \pm 3.7 ) and complexity (SSC: 6.2-32.3) same FL1 excitation when compare to other leucocytes.

This is the first report of the phenotype of blood cells by 3,3-dihexyloxacarbocyanine [ $\left.\mathrm{DiOC}_{6}(3)\right]$ in flow cytometry of white-eyed parakeets ( $P$. leucophtalmus). We believed this report could to be an inspiration for other studies dedicated in avian hematology, immunopathology and disease effects in avian clinics. Fotopoulos (2012) claims that $\mathrm{DiOC}_{6}(3)$ can revisited and several new application potentials have emerged in haematological, inflammatory and immune response studies.

The methodology of $\mathrm{DiOC}_{6}(3)$ stain associated with flow cytometry has managed to get around the hematologic automatization ceilings were the nucleation of erythrocytes and thrombocytes associated the variability of cell morphology among the existing large number of avian species make it difficult the counting and differentiation in species with nucleated blood cells (Walberg 2001). Flow cytometry is widely used on human and mammals samples and provides a rapid and precise for detecting, counting and characterizing cells in mixed populations (Morgan et al. 1993, Inoue et al. 2002).

The $\mathrm{DiOC}_{6}(3)$ staining was useful for distinguishing the white-eyed parakeets leucocyte from erythrocytes like the reported for common carp (Cyprinus carpio), green iguana (Iguana iguana) and quail (Coturnix coturnix) (Inoue et al. 2002, Moritomo et al. 2002, Uchiyama et al. 2005). Even though our experiment not used cell sorting for to identify in light microscopy the cellularity, the cytometric behavior was the same found in literature and similar distribution when compared with leukocytograms of dogs and cats based on size and complexity (FSC vs. SSC) (De Boever et al. 2010).

Sun et al. (2010) defined three subpopulations peripheral blood of penaeid shrimp (Penaeus vannamei) based on the relative size and complexity - granulocytes, semi-granulocytes and smallest cells that the authors classified as hyalinocytes that can be compared to lymphocytes to the nucleus that fills the entire cytoplasm and without granulations.

Morgan et al. (1993) in their results of fish blood marked with acridine orange (AO) gated four population in FSC x SSC plot, erythrocyte, lymphocytes/thrombocytes, monocytes and granulocytes (heterophile/eosinophils). In these stains $\left[\mathrm{AO}\right.$ and $\left.\mathrm{DiOC}_{6}(3)\right]$ is problematic cytometric differentiation concerning heterophils from eosinophils; thrombocytes from small lymphocytes and large lymphocytes from monocytes (Inoue et al. 2002). Currently, there is no standard automated technique for blood count and differentiation in avian species.

An alternative to complement this differentiation is the use of monoclonal antibodies specific for each cell type may allow counting all the leucocyte subtypes in the whole blood (Seliger et al. 2012). There are immunophenotyping that has been reported in commercial poultry (Burgess \& Davison 1999, De Boever et al. 2010, Seliger et al. 2012), meantime, the antibody is not commercially available for the different avian species. It is necessary to validate the poultry specific antibodies with other avian species.

Bohls et al. (2006) used immunophenotyping of K1 (a thrombocyte and macrophage marker), to distinguish better the thrombocyte from the lymphocyte population, which is positive for K55 (leucocyte marker) in Leghorn chickens. Another example, the authors performed immunophenotyping antiCD-45 in blood samples from commercial laying hens in an attempt to separate lymphocytes from thrombocytes (De Boever et al. 2010) but mostly these markers only available was conjugated with FITC that makes it impossible to use multicolour panel.

The population containing thrombocytes and lymphocytes (R2-3) could not be separated by using $\mathrm{DiOC}_{6}(3)$ staining. Ours results were similar that discussed in other papers, the $\mathrm{DiOC}_{6}(3)$ were not effective either in distinguishing these two cell types due to similar cytometry characteristic of them. FACS analysis employing both monoclonal antibodies against thrombocytes and $\mathrm{DiOC}_{18}(3)$ should be able to count all the cell types in blood (Morgan et al. 1993, Inoue et al. 2002, Moritomo et al. 2002, Uchiyama et al. 2005).

An earlier study in the literature demonstrated that the contamination of the lymphocyte population with thrombocytes could be as high as $70 \%$ in avian blood samples, even in protocols that separate the mononuclear cells by the density gradient (Bohls et al. 2006).

\section{CONCLUSIONS}

Our study determined that the predominant population in white-eyed parakeet (Psittacara leucophthalmus) was lymphocytes, thrombocytes and monocytes in the leucocytes gates in comparison the granulocyte population.

We believe that the present study open up an opportunity for the study of leukocytes in parrots and also in other animals with nucleated erythrocytes for which of haematological automation and flow cytometer is limited. With a feasible and easily reproducible methodology, it will be possible to

Table 1. Results of whole blood cells of free-living young white-eyed parakeet (Psittacara leucophthalmus) stained with 3,3-dihexyloxacarbocyanine $\left[\operatorname{DiOC}_{6}(3)\right]$ acquired by flow cytometry

\begin{tabular}{|c|c|c|c|c|c|}
\hline $\begin{array}{l}\text { P. leucophthalmus } \\
\text { (n = 19) }\end{array}$ & $\begin{array}{l}\text { (R1) } \\
\text { RBC }\end{array}$ & $\begin{array}{l}\text { (R2) } \\
\text { WBC }\end{array}$ & $\begin{array}{l}\text { (R2-1) } \\
\text { GRAN }\end{array}$ & $\begin{array}{l}\text { (R2-2) } \\
\text { MON }\end{array}$ & $\begin{array}{c}\text { (R2-3) } \\
\text { LYM/THR }\end{array}$ \\
\hline$(\%)$ & $\begin{array}{c}58.3 \\
(44.7-71.9)\end{array}$ & $\begin{array}{c}32.4 \\
(19.3-45.5)\end{array}$ & $\begin{array}{c}9.7 \\
(5.9-26)\end{array}$ & $\begin{array}{c}30.6 \\
(22.1-39.1)\end{array}$ & $\begin{array}{c}29.7 \\
(22-37.4)\end{array}$ \\
\hline $\begin{array}{c}\text { FSC } \\
\text { cell weight }\end{array}$ & $\begin{array}{c}146.3 \\
(103.6-168.7)\end{array}$ & $\begin{array}{c}104 \\
(93.8-114.2)\end{array}$ & $\begin{array}{c}93 \\
(81.4-104.6)\end{array}$ & $\begin{array}{c}147 \\
(136.7-157.3)\end{array}$ & $\begin{array}{c}73.6 \\
(69.9-77.3)\end{array}$ \\
\hline $\begin{array}{c}\text { SSC } \\
\text { complexity }\end{array}$ & $\begin{array}{c}56 \\
(51.6-60.4)\end{array}$ & $\begin{array}{c}37 \\
(33.3-40.7)\end{array}$ & $\begin{array}{c}120.4 \\
(8.6-136.3)\end{array}$ & $\begin{array}{c}31.9 \\
(8.6-39.6)\end{array}$ & $\begin{array}{c}22 \\
(6.2-32.3)\end{array}$ \\
\hline
\end{tabular}

$\mathrm{RBC}=$ Red blood cells, WBC $=$ white blood cells, GRAN $=$ granulocytes, MON $=$ monocytes, LYM $/$ THR $=$ lymphocytes $/$ thrombocytes, FSC $=$ forward scatter, SSC $=$ side scatter . 
investigate leukocyte behavior in understanding natural or experimental infectious processes. If there is the possibility of physical separation of blood cellularity by flow cytometry (sorting), it will be possible to conduct in-vitro assays with cell cultures as cycle cell, cell viability and activation, and others. Furthermore, the use of $\operatorname{DiOC}_{6}(3)$ stain is not possible distinguish the lymphocytes and thrombocytes. The cytometry method and use of DiOC $_{6}(3)$ stain was available for parakeets blood samples and can be studied and applied to other species of parrots.

This seems to be the first report on blood phenotypic analysis of parrots of the Psittacara spp.

Authors' contribution.- Authors will declare the contribution of each author like NRNC and MDS conceived and designed the review/project/study. NRNC, MDS and AES executed the experiment and cytometry analysis of blood cells stained. LANB and KW revised manuscript and english language. All authors interpreted the data, critically revised the manuscript for important intellectual contents and approved the final version.

Conflict of interest statement.- The authors declare that they have no competing interests.

\section{REFERENCES}

Bohls R.L., Smith R., Ferro P.J., Silvy N.J., Li Z. \& Collisson E.W. 2006. The use of flow cytometry to discriminate avian lymphocytes from contaminating thrombocytes. Develop. Comp. Immunol. 30(9):843-850.<https://dx.doi. org/10.1016/j.dci.2005.10.008> <PMid:16360205>

Burgess S.C. \& Davison T.F. 1999. Counting absolute numbers of specific leukocyte subpopulations in avian whole blood using a single-step flow cytometric technique: comparison of two inbred lines of chickens. J. Immunol. Methods 227(1/2):169-176. <https://dx.doi.org/10.1016/ S0022-1759(99)00083-6><PMid:10485264>

Clark P.W., Boardman W. \& Raidal S. 2009. Atlas of Clinical Avian Hematology. Wiley-Blackwell, Iowa. 198p.

De Boever S., Croubls S., Demeyere K., Lambrecht B., De Backer P. \& Meyer E. 2010. Flow cytometric differentiation of avian leukocytes and analysis of thei intracellular cytokine expression. Avian Pathol. 39(1):41-46. <https://dx.doi.org/10.1080/03079450903473574><PMid:20390535>
Fotopoulos V. 2012. Never say dye: new roles for an old fluorochrome. Plant Signal. Behav. 7(3):342-344. <https://dx.doi.org/10.4161/psb.19236> $<$ PMid:22476459>

Inoue T., Moritomo T., Tamara Y., Mamiya S., Fujino H. \& Nakanishi T. 2002. A new method for fish leucocyte counting and partial differentiantion by flow cytometry. Fish Shellfish Immunol. 13(5):379-390. <https://dx.doi. org/10.1006/fsim.2002.0413><PMid:12458744>

Morgan J.A.W., Pottinger T.G. \& Rippon P. 1993. Evaluation of flow cytometry as a method for quantification of circulating blood cell populations in salmonid fish. J. Fish Biol. 42(1):131-141.<https://dx.doi.org/10.1111/j.1095-8649.1993. tb00311.x>

Moritomo T., Minami A., Inoue Y. \& Naknishi T. 2002. A new method for counting of quail leukocytes by flow cytometry. J. Vet. Med. Sci. 64(12):1149-1151. <https://dx.doi.org/10.1292/jvms.64.1149> <PMid:12520111>

R Core Team. 2011. R: a language and environment for statistical computing. R Foundation for Statistical Computing, Vienna. Available at <http:// www.R-project.org> Accessed on June 9, 2021.

Sabnis R.W., Deligeorgiev T.G., Jachak M.N. \& Dalvi T.S. 1997. DiOC 6 (3): a useful dye for staining the endoplasmic reticulum. Biotech. Histochem. 72(5):253-258. <https://dx.doi.org/10.3109/10520299709082249> $<$ PMid:9408585>

Seliger C., Schaerer B., Kohn M., Pendl H., Weigend S., Kaspers B. \& Härtle S. 2012. A rapid high-precision flow cytometry based technique for total white blood cell counting in chickens. Vet. Immunol. Immunopathol. 145(1/2):86-99. <https://dx.doi.org/10.1016/j.vetimm.2011.10.010> $<$ PMid:22088676>

Sun J., Wang A. \& Zhang T. 2010. Flow cytometric analysis of defense functions of hemocytes from the penaeid shrimp, Penaeus vannamei. JWAS 41(1):92-105. <https://dx.doi.org/10.1111/j.1749-7345.2009.00316.x>

Uchiyama R., Morimoto T., Kai O., Uwatoko K., Inoue Y. \& Nakanishi T. 2005. Counting absolute number of lymphocytes in quail whole blood by flow cytometry. J. Vet. Med. Sci. 67(4):441-444. <https://dx.doi.org/10.1292/ jvms.67.441><PMid:15876797>

Walberg J. 2001. White blood cell counting techniques in birds. J. Exot. Pet Med. 10(2):72-76. <https://dx.doi.org/10.1053/saep.2001.22051>

Welles E.G., Hall A.S. \& Carpenter D.M. 2009. Canine complete blood counts: a comparison of four in-office instruments with the ADVIA 120 and manual differential counts. Vet. Clin. Pathol. 38(1):20-29. <https://dx.doi. org/10.1111/j.1939-165X.2008.00084.X><PMid:19228360> 